[Електронний ресурс]: URL: http://ualib.com.ua/ br_6601.html.

4. Морзе Н. В. Моделі ефективного використання інформаційно-комунікаційних та дистанційних технологій навчання у вищому навчальному закладі [Електронний ресурс] / Н. В. Морзе, О. Г. Глазунова // Інформаційні технології і засоби навчання. 2008. № 2. URL: http://www.nbuv.gov.ua/ejournals/ITZN/em6/emg.htm 1 .

5. Освітній портал [Електронний ресурс]: URL:www.osvita.org.ua/distance/.

6. Шляхи модернізації вищої освіти в контексті євроінтеграції: матеріали регіонального науково-практичного семінару / за заг. ред. Г. В. Терещука. Тернопіль: Вид-во ТНПУ ім. В. Гнатюка, 2008. 235 с.

7. http://moodle.kspu.kr.ua $=106$

8. http://moodle.kspu.kr.ua/course/view.php?id $=194$

9. http://moodle.kspu.kr.ua/enrol/index.php?id

10. http://moodle.kspu.kr.ua/course/view.php?id $=116$

\section{REFERENCES}

1. Boiko, N. I. (2008). Orhanizatsiia samostiinoi roboty studentiv vyshchykh navchalnykh zakladiv $v$ umovakh zastosuvannia informatsiinokomunikatsiinykh tekhnolohii. [Organization of independent work of students of higher educational institutions in the conditions of application of information and communication technologies]. Kyiv.

2. Brodskyi, H. L., Shevchenko, I. L. (2019). Suchasni tekhnolohii vykladannia muzychnykh dystsyplin $u$ zakladakh vyshchoi osvity. [Modern technologies of teaching of musical disciplines in the establishments of higher education]. Kirovohrad.

3. Korotkyi terminolohichnyi slovnyk z innovatsiinykh pedahohichnykh tekhnolohii. [Short terminology dictionary on innovative pedagogical technologies] [Elektronnyi resurs]: Elektronna on-lain biblioteka: - Rezhym dostupu: http://ualib.com.ua/ br $6601 . \mathrm{html}$.

4. Morze, N. V. (2008). Modeli efektyvnoho vykorystannia informatsiino-komunikatsiinykh to dystantsiinykh tekhnolohii navchannia u vyshchomu navchalnomu zakladi. [Models of effective use of information and communication and distant learning technologies in higher education] [Elektronnyi resurs]:Rezhym dostupu: http://www.nbuv.gov.ua/ ejournals/ITZN/em6/emg.html.

5. Osvitnii portal. [Educational portal] [Elektronnyi resurs]: - Rezhym dostupu: www.osvita. org.ua/distance/.

6. Shliakhy modernizatsii vyshchoi osvity $v$ konteksti yevrointehratsii: materialy rehionalnoho naukovo-praktychnoho seminaru. (2008). [Ways to modernize higher education in the context of European integration]. Ternopil.

7. http://moodle.kspu.kr.ua $=106$

8. http://moodle.kspu.kr.ua/course/view.php?id

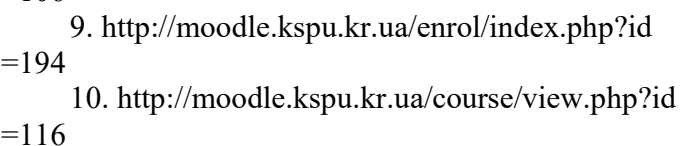

\section{ВІДОМОСТІ ПРО АВТОРА}

ШЕВЧЕНКО Інга Леонідівна - кандидат педагогічних наук, доцент кафедри вокальнохорових дисциплін та методики музичного виховання Центральноукраїнського державного педагогічного університету імені Володимира Винниченка.

Наукові інтереси: особливості професійної підготовки студентів мистецьких факультетів педагогічних вищих навчальних закладів у рамках сучасної гуманітарно-культурологічної парадигми.

\section{INFORMATION ABOUT THE AUTHOR}

SHEVCHENKO Inha Leonidivna - Ph.D., Associate Professor Department of Vocally-Choral Disciplines and Methodology of Musical Education Centralukrainian State Pedagogical University named Volodymyr Vinnichenko.

Circle of scientific interests: features of professional training of students of art faculties of pedagogical universities in the framework of the current humanitarian and cultural paradigm.

Стаття надійшла до редакиї 20.01.2020 p.

SHCHERBYNA Svitlana Volodymyrivna Candidate of Pedagogical Sciences (Doctor of Philosophy), Associate Professor of the Department of Foreign Languages of Central Ukrainian National Technical University ORCID:https://orcid.org/0000-0003-2729-4267 e-mail: 2108sveta64@gmail.com

\title{
SOME METHODOLOGOCAL ASPECTS IN TEACHING FOREIGN LANGUAGE READING
}

Formation and justification of the relevance of the problem. One of the important parts in teaching foreign language is reading.
Most books on English teaching methodology concentrate on the manipulative phase of language teaching - the phase in which students 
learn basic language structure through reading, drills and exercises. Particularly disappointing is that students who have endured long hours of study are deprived of the satisfaction of expressing themselves in progressively creative context, because their teacher lacks adequate material on conversation techniques. Appropriate selection of reading material and different approaches can help to make learning foreign languages more effective.

Analysis of resent research and publications. There are different approaches to teaching reading in modern scientific literature. Thus, Bruffe K., Graff G., Hidi S. and Anderson V. pay attention to situational interest and its impact on reading. Nunan D. consider task-based syllabus design, Schiefel V., Schaw G. and Dennison R.S. study the problem of topic interest and levels of text comprehension. Frank M., Harmer G., Celce-Muricia M. investigate the problem of how to make teaching of reading temporary, productive and interesting. Armstrong T., Gardner H., Norman D. A., Pieget J. develop the theory of multiple intelligence through reading tasks.

The purpose of the article is to analyze different approaches to reading instruction, show its advantages in teaching of foreign language and offer some methods in teaching of reading.

The main material of the study. Realworld reading is performed for any number of reasons, and the nature of reading varies according to the reader's purpose and situation. These factors inevitably determine the readers approach to the text, the amount of attention paid, the time spent, as well as what features or parts of the text are focused on.

Whether we are reading for pleasure or information, the nature of the reading depends of what we want from the text, as well as situational factors such as time available or constraints relative to place of reading. No matter what our agenda, why and where we read inevitably determined how we read.

Wherever possible, instructors should ask students directly about their interests and provide them with choices of authentic texts. But reader interest in a text can also be a function of purpose. Educational researchers have defined several different categories of interest. Individual or personal interest refers to long-standing preferences on the part of a particular reader for certain topics or related subject matter [8, p. 160]. By contrast, situational interest refers to interest generated by situational factors, including the text itself. Text based situational interest is generally defined as interest that elicited by text through topics or ideas that are of universal or archetypal appeal [4, p. 222]. Another form of situational interest, and one of that concerns us here, is reading purpose.

In a study that sought to determine the effect on interest and recall of reading with a particular perspective, Schraw and Dennison [9] found that focusing readers' attention on selected text information increases what the researches term purpose-driven interest and that text segments that are relevant to a readers' purpose are recalled better than those that are not.

Reading with a purpose means approaching texts with a specific goal. When possible, students can be asked to read a text from a specific point of view, depending on what the text might suggest. In the classroom, students can be given reasons to read that approximate their purposes in a variety of real-world situations. They can read ads for apartments to find one that fits a particular set of requirements, look through movie listings and reviews to decide whether to see a particular movie, or respond to a written invitation.

Beyond these comprehension exercise types, purposeful reading can also be part of whole communicative tasks in the foreign language classroom. Nunan defines a communicative task as a «piece of classroom work which involves learners in comprehending, manipulating, producing, or interacting in the target language while their attention is focused on meaning rather than form» [6, p. 59]. Strictly speaking, in task activities, the goal is nonlinguistic. The idea is to get something done via the language, to read a text and do something with the information [5, p. 28]. Whole tasks involve performance of reading in conjunction with other skills: listening, speaking or writing. For example, students in a small group might read a number of texts, such as brochures, timetables or maps, and listen to radio weather or traffic reports in order to carry out the larger task of deciding on the best method of transportation to use on a trip. In such an activity, each student deals with one category of information, and all students must communicate their information to one another to come up with the best plan for the trip.

Still other kinds of communicative tasks may be activities that would not actually occur in real-world situations. For example, a classroom reading task might involve students drawing a picture based on a written text, reconstructing a text that has been cut up into paragraphs, or, in pairs, reading slightly different versions of the same story and discovering differences through speech alone. These tasks, while not real world, are still communicative; the focus is on 
understanding a text to get something done.

A task approach conveys to students the value of influent and efficient reading, because reading for a specific purpose means reading texts in different ways at different speeds, depending on the information needed and the task to be carried out. Another advantage of tasks is that students can work with authentic texts from the start. A complex, unedited text can be made accessible by a adjusting the level of difficulty of the task. The same text can be used at different points during a semester, each time with a different task or purpose. In reading the same text with a different purpose, students derive a sense of accomplishment from their progressively greater comprehension and more extended use of the text.

Recent reading research points the benefits of working with texts for the purpose of drawing students' attention to formal features of written language as well [5, p. 32]. A communicative or task approach can and should be combined with analysis of text structure and linguistic features of text; however, most specialist concur that instructors should focus on textual messages first. If an individual student cannot perform a task successfully due to misreading of a text, the student will need to reread problematic segments and attend more closely to the text structure. If many students in a class experience difficulty with certain syntactical structures or forms of text organization, the instructor may choose to conduct a reading lesson that targets those areas.

Students can be led from consideration of content to those of form in a natural manner. In the domain of theoretic, for example, students can be asked to identify the discourse features of the text that contribute to its persuasiveness. They can focus on pragmatic issues pf register and audience and examine the lexical networks that connect text segments and the use of syntax to establish topic and theme. Textual analysis of this sort is a different kind of activity from reading to perform a communicative task. Both uses of text are beneficial, but it is necessary for instructors and students to distinguish between them. It is also important that a text be apprehended first in terms of meaning and reader response.

In advance-level courses, such a film studies or special topics in literature, the realworld uses of text are less evident; rather, the focus is on academic tasks. In most academic tasks, such as presenting a report or writing a paper, reading plays a significant role.

In discussions of the concept of critical literacy, reading and interpretation have been defined by a variety of researches as being able to talk about a text, which in turn means being able to participate in a «conversation of readers» [3, p. 18]. In this view, literacy is both a social and cognitive process.

Importantly, Graff situates reading within the larger communicative context of academic discourse and emphasizes the primacy of context over the text. He argues that reading a literary text in order to support or counter a particular critical argument can engage students who otherwise would not know what to think or say what they are reading. Thus, in literature courses, an important sense of purpose can be creating by asking students to read from a particular angle or with a particular argument in mind.

Literacy tasks for upper-level coursework should afford diverse opportunities for interaction among students. In a discussion of academic discourse and collaborative learning, Bruffee [1, 42] borrows the Vygotskian concept of thought as international conversation to argue for «engaging students in conversational among themselves at as many points in both the writing and the reading process as possible», in short, for pedagogical practice that acknowledges and reflects the social and inter-textual nature of literacy and knowledge. This means less emphasis on reading as a solitary activity and more on reading and talking with others.

A reader's background knowledge with respect to text topic and genre as a significant factor in text comprehension. As a result, textbooks and pedagogical practice now routinely include pre-reading activities with authentic texts or other reading selections. Interestingly, a benefit of such activities is the focus or purpose for reading that they can provide. The value of pre-reading work for both comprehension and interest does not diminish at the advanced level. In literature courses, for example, writing and discussion can serve equally well as an entry into the whole text or text segment. Pre-reading discussion can focus on a critical argument or controversy surrounding interpretation of a text. More simply, discussion or writing tasks can elicit students' personal views or previous reading on a topic or their expectations with respect to text content or point of view. Students familiar with American and Ukrainian newspapers can be asked to compare articles from The Washington Post or USA Today on terrorism. Prior to the reading, they can articulate their expectations about what facts will be highlighted and what perspective or political stance, if any, the articles will reflect. Discussing these issues before rather than after reading provides focus, which in turn 
creates interest in the texts.

As preparation for reading authentic foreign language texts on a cultural topic, students can engage in peer reading and debate. In this activity, the instructor provides students with a topic for debate formulated in terms of a specific questions. Each student writes a short position statement on the topic, making an argument that may or may not represent their view. In groups, students read through and discuss all statements culling what they believe to be the best arguments for and against each side of the debate. The groups than compare their results. Again, prior discussion of the arguments provides a focal point for reading.

At the presentation stage the teacher's main task is to serve as a kind of informant. He/she knows the language, selects the new material to be learned (using the textbook normally but supplementing and modifying it as required) and presents this in such a way that the meaning of the new language is as clear and memorable as possible. The students read and try to understand. Although they are probably saying very little at this stage, except when invited to join in, they are by no means passive.

Writing is a particular effective form of prereading activity that prompts readers to reflect on what they are about to read. Writing activities foster the development of a sense of authorship, which in turn helps make students more critical readers. An effective way to promote active response to text is through assignment of reading journals. In these, students write entries prior to each reading assignment. In addition to write their reactions to text passages already read, they are encouraged to write their prospectively, anticipating story line or character development and formulating questions about what they are about to read. Journal entries are handed in to the instructor or exchanged with other students and form the basis for discussion or for other, more developed writing tasks.

It should be stressed, that translation plays also a great role in the process of reading.

The active terminology vocabulary of students saves his working time. Such terms are collected in the process of work, the stuff is determined by the content of the work.

Some terms and their building can be divided according to some certain principles but some terms are not classed; they are not to be remembered. The list of them is following:

Paronyms;

British-American Correspondences; Forms;

Measurements and Their Abbreviated

«False Friends»;
Traditional Stamps;

Latinisms;

Obsolete Adverbs;

Special Affixation Examples;

General Abbreviations and Acronyms; etc.

The arrangement of the abovementioned terms into special tables and charts are of great help foe the students. In time he will learn them and be able to distinguish them if he has them in hand in the beginning of reading. The students make the tables for themselves and at the first stage the teacher can provide them with all the brief reference material. It depends on the students' level and abilities.

Another important aspect as for reading, its multiple intelligence applied to transforming texts through graphic responses. Probably no aspect of contemporary psychology is more misunderstood by the general public than intelligence. We seem to be awed by our perception of intelligence in others. It has a profound effect on social status, educational opportunities, and career choices. Yet, despite all the importance attached to intelligence, most of us seem unable to define exactly what intelligence means. The debate among psychologists themselves talk about intelligence in two different ways. The first is to use intelligence to refer intelligence acts. Such as writing a book or designing a new computer. The second way is to use intelligence to refer to mental processes that give rise to intelligence acts, such as mental abilities that underline intelligence acts (such as inferring, analyzing, reasoning or deducing). One view says that, for example, Mozart was born with a specific talent to write his music, and the other extreme says that it was an accident of time and place, and that anyone could have written what Mozart wrote. Neither extreme view is very attractive. In fact, most psychologists take an intermediate view, stating that some finite set of multiple processes gives rise to a full range of intelligence human activities. Much of the work on mental processes has been to bridge the gap between these intelligent acts and processes.

In general, there three different psychological perspectives on intelligence. The first is psychometric tradition. This tradition represents the branch of psychology that has been concerned primarily with developing tests to measure intelligence. The next view of intelligence is the information-processing perspective [2, p. 35]. It is an outgrowth of experimental psychology and provides descriptions theories and mental activities that compose intelligence. The third traditional view of intelligence comes from cognitive 
developmental psychology and associated with the work of Jean Piaget [7, p. 8], which investigated intellectual development. Several commonalities exist among these three perspectives. First, all three perspectives are concerned with knowledge, skills and activities. Another commonality is that adaptability is considered important component of intelligence. Measured intellectual skills depends on one's success in dealing with novel stimuli and tasks, not with familiar ones.

In response to these perspectives comes Gardner's theory of Multiple Intelligence [2, p. 47] based upon the fact that a human intellectual competence must entail a set of skills of problem solving - enabling the individual to resolve genuine problems or difficulties that he or she encounters and when appropriate, to create an effective product, and must also entail the potential for finding or creating problems thereby laying the groundwork for the acquisition of new knowledge.

The theory establishes seven distinct intelligences that can be developed over a lifetime. According to Gardner, intelligence is not a single construct, nor is it considered static. The theory is very important to foreign language teachers because we work with such diverse learners. Through multiple intelligence theory we can nurture intelligences in many different ways. Multiple Intelligence theory helps educators to create an individualized learning environment.

There are many reasons why getting students to read texts is an important part of the teacher's job. In the first place, many of them want to be able to read texts in English either for their careers, for study purposes or simply for pleasure. Anything we can do to make reading easier for them must be a good idea.

Reading texts also provides opportunities to study language: vocabulary, grammar, punctuation, and the way we construct sentences, paragraphs and texts. Lastly, good reading texts can introduce interesting topics, stimulate discussion, excite imaginative responses and be the springboard for well-rounded, fascinating lessons.

One of the greatest enemies of successful teaching is student boredom. This is often caused by the deadening predictability of much classroom time. Students frequently know what is going to happen in class and they know this because it will be the same as what happened in the last class - and the whole string of classes before that. Something has to be done to break the chain. Both for teacher's sanity and the students continuing involvement, teachers need to violate their old methods of teaching. Each time teachers should change one of their methods, in other words, they send a ripple through the class. That ripple is a mixture of surprise and curiosity and it is a perfect starting point for student involvement.

The need for surprise and variety within an hour lesson is also overwhelming. If for example, students spend all of that time writing sentences, they will probably get bored. But if, that hour lesson, there are a number of different tasks with a selection of different topics, the students are much more likely to remain interested. This can be seen most clearly with the pupils at primary and secondary levels, but even adults need a varied diet to keep them stimulated.

What reading skills should students acquire? Students, like the rest of us, need to be able to do a number of things with a reading text. They need to be able to scan the text for particular bits of information they are searching for. This skill means that they do not have to read every word and line; on the contrary, such an approach would stop them scanning successfully.

Students need to be able to skin a text - as if there were casting their eyes over its surface to get a general idea of what it is about. Just as with scanning, if they try to gather all the details at this stage, they will get bogged down and may not be able to get the general idea because they are concentrating too hard on specifics.

Whether readers scan or skim depends on what kind of text they are reading and what they want to get out of it. They may scan a computer manual to find the one piece of information they need to use their machine, and they skim a newspaper article to get a general idea of what's been happening. But we would expect them to be less utilitarian with a literary work where reading for pleasure will be a slower, closer kind of activity.

Reading for detailed comprehension, whether looking for detailed information or language, must be seen by students as something very different from reading skills mentioned above. When looking for details, we expect students to concentrate on the minutiae of what they are reading.

Thereby, how to bring up the work with the text or a poem. Below there is a list of proposals.

1. Give each students a card of the words.

2. Students have to find the meaning of each word (matching exercises).

3. Checking words work.

4. Discussion. What will the text be about? 
5. Listening to the text (record). One time.

6. Very short retelling. What is the text about?

7. Listening to the text for the second time.

8. Students have to fold down the card, look at the list of new words and arrange the words in order they appear in the text.

9. Students have to discuss the list order with the neighbor.

10. Discussion the word order with the teacher.

11. Each student is given the envelope. There are cards with the sentences of the text. Students have to arrange the text in the right order.

12. Listening to the text for the third time. Checking the text.

13. Teacher's questions. Who is the author? When was the story written? What is the title?

14. Students have to divide the text into parts.

15. Discussion. What is each part about? Describing the hero, his life, historical period, etc.

16. The teacher is giving students the text with gaps they have to fill with the right order.

17. Home task is to write a story with new words.

Conclusions and prospects for further research of the direction. Having analyzed the current scientific positions, it can be concluded that the integral part of teaching foreign languages is teaching reading. There are different approaches to teaching reading. One of them is teaching communicative reading and focuses on the factor of purpose, as determined by the reader or the instructional context. As we can see, tapping into one's learning styles and strategies helps all students, not only second language learners, but gifted students, mainstream students, and those with special needs. Fortunately, teaching reading is slowly revolutionizing and teachers are being equipped with the right tools to serve the needs of their students. Educators realize that there is no one correct way to teach a student and there are innumerable manners in which for them to learn. If both student and teacher are able to identify their strengths, they can work as partners toward scholastic achievement.

\section{СПИСОК ДЖЕРЕЛ}

1. Bruffee K.A. 1984. Collaborative learning and the «conversation of mankind». College English, 46. P. $35-52$.

2. Gardner H. 1993. Multiple Intelligences: The theory and Practice. New York: Basic books. 140 p.
3. Graff G. 1992. Beyond the cultural wars: How teaching conflicts can revitalize American education. New York: W.W. Norton. 281 p.

4. Hidi S., \& Anderson V. Situational interest and its impact on reading and expository writing. In K.A. Renninger, S.Hiddi \& A.Krapp, Eds., The role of interest in learning and development - Hillsdale, $\mathrm{NJ}$ : Lawrence Earlbaum. 1992. P. 215-238

5. Long M.H.\& Crookes G. 1992. Three approaches to task-based syllabus design. TESOL Quarterly, 26. P. 27-56.

6. Nunan D. 1993. Task-based syllabus design: Selecting, grading and sequencing tasks. In G.Crookes \& S.Gass, Eds., Tasks in pedagogical context: Integrating theory and practice. - Clevedon: Multilingual Matters. $386 \mathrm{p}$.

7. Piaget J. 1972. The psychology of intelligence. New York: International Universities Press. 128 p.

8. Schiefel U. 1992. Topic interest and levels of text comprehension. In K.A. Renninger,S.Hidi \& A.Krapp, Eds. The role of interest in learning and development Hillsale, NJ: Lawrence Earlbraum. P. $151-182$

9. Schaw G. \& Dennison R.S. 1994. The effect of reader purpose on interest and recall. Journal of Reading Behaviour, 26. P.1-17

\section{REFERENCES}

1. Bruffee, K. A. (1984). Navchannya ta «rozmova lyudstva». [Collaborative learning and the «conversation of mankind»]. College English.

2. Gardner, H. (1993). Kil'ka intelektual'nykh teoriy: teoriya ta praktyka. [Multiple Intelligences: The theory and Practice]. New York.

3. Graff, G. (1992). Poza mezhamy kul'turnykh viyn: yak navchal'ni konflikty mozhut' pozhvavyty amerykans'ku osvitu. [Beyond the cultural wars: How teaching conflicts can revitalize American education]. New York.

4. Hidi, S., \& Anderson, V. (1992). Sytuatsiynyy interes ta yoho vplyv na chytannya ta opys zapysiv. $U$ K. A. Renninher, S.Khiddi ta A.Krapp, redaktsiya, rol interesu do navchannya ta rozvytku. [Situational interest and its impact on reading and expository writing. In K.A. Renninger, S.Hiddi \& A.Krapp, Eds., The role of interest in learning and development Hillsdale]. NJ

5. Long, M.H.\& Crookes, G. (1992). Try pidkhody do rozrobky navchal'nykh prohram na osnovi zavdan'. [Three approaches to task-based syllabus design].

6. Nunan, D. (1993). Dyzayn navchal'nykh prohram na osnovi zavdan': vybir, klasyfikatsiya ta poslidovnist' zavdan'. U roboti G.Crookes \& S.Gass, red., Zavdannya $v$ pedahohichnomu konteksti: intehratsiya teoriyi ta praktyky. [Task-based syllabus design: Selecting, grading and sequencing tasks. In G.Crookes \& S.Gass, Eds., Tasks in pedagogical context: Integrating theory and practice].

7. Piaget, J. (1972). Psykholohiya intelektu. [The psychology of intelligence]. New York.

8. Schiefel, U. (1992). Interes do temy ta rivni rozuminnya tekstu. U K.A. Renninher, S.Khidi ta A.Krapp, Eds. Rol' interesu do navchannya ta 
rozvytku Hillsale. [Topic interest and levels of text comprehension. In K.A. Renninger, S.Hidi \& A.Krapp, Eds. The role of interest in learning and development Hillsale]. NJ.

9. Schaw, G. \& Dennison, R.S. (1994). Vplyv chytats'koyi mety na interes ta z haduvannya. Zhurnal povedinky chytannya. [The effect of reader purpose on interest and recall. Journal of Reading Behaviour].

\section{ВІДОМОСТІ ПРО АВТОРА}

ЩЕРБИНА Світлана Володимирівна кандидат педагогічних наук (доктор філософії), доцент кафедри іноземних мов Центральноукраїнського національного технічного університету.
Наукові інтереси: теорія та методика навчання іноземним мовам.

\section{INFORMATION ABOUT THE AUTHOR}

SHERBYNA Svitlana Volodymyrivna Candidate of Pedagogical Sciences (Doctor of Philosophy), Associate Professor of the Department of Foreign Languages of Central Ukrainian National Technical University.

Circle of research interest: theory and methodology of teaching foreign languages.

Стаття надійшла до редакиіï 23.01.2020 p.

УДК 378.015.311

DOI: 10.36550/2415-7988-2020-1-188-170-173

РОЙТЕНКО Ніна Олексіївна -

приват-доцент, старший викладач кафедри теорії музики і вокалу Південноукраїнського національного педагогічного університету ім. К. Д. Ушинського

ORCID:https://orcid.org/0000-0003-3598-9291 e-mail:pednauk@gmail.com

\section{ОРФОЕПІЧНІ НОРМИ У ТВОРЧОСТІ СТУДЕНТІВ-ВОКАЛІСТІВ У КОНТЕКСТІ СЛОВ'ЯНСЬКИХ МОВ}

\begin{abstract}
Постановка та обгрунтування актуальності проблеми. Студенти-вокалісти останнім часом все частіше звертаються 3 проханням до викладача включити у свою програму твори західноєвропейських авторів ï рідною мовою. Пов'язано це 3 тим, що починаючі співаки прагнуть у майбутньому стати професійними фахівцями в області академічного, естрадного та народного співу. У зв'язку з історичним процесом інтеграції України до Європи великого значення набувають культурні зв'язки між цими країнами. Особливо гостро ця проблема постає зараз, в епоху переходу суспільства до соціальної стабільності суспільної думки, при зростаючому престижі освіти та прагненні до високого рівня особистої культури. В сучасному суспільстві ми просліджуємо все більш зростаючу увагу дослідників у галузі освіти до застосування інтернету. Це стосується і підготовки викладача-музиканта у вищому навчальному закладі, тобто підготовки музиканта-педагога 3 високим рівнем професійних знань та вмінь, який володітиме високою педагогічною та духовною культурою, а також творчими здібностями. Використання сучасних інформаційних технологій, на наш погляд, дає можливість вирішувати конкретні професійні завдання. Дослідники I. Горбунова, А. Панкова на своєму багатолітньому педагогічному досвіді зробили висновок про
\end{abstract}

високу ефективність застосування МКТ (музично-комп'ютерна технологія) 3 метою занурення майбутніх педагогів-музикантів в сучасне, високотехнологічне, інформаційне освітне середовище для успішного використання отриманих знань у майбутній професійній діяльності. Автори підкреслюють, що це відкриває перспективи до пізнання нових можливостей для творчого експерименту, розширення пізнавального кругозору студентів, оптимізації навчального процесу, щоб зробити його високохудожнім $\mathrm{i}$ високотехнологічним, який відповідав би потребам сучасного освітнього середовища. Використання та застосування МКТ у підготовці майбутнього педагога-музиканта забезпечує не тільки природність процесу навчання, але й викликає великий інтерес i збільшує долю та ефективність самостійної роботи студента, скорочує час на техніку орфоепічних норм у вимовлянні літературного тексту. Тому великого значення набуває відродження національних традицій, спрямованих на актуалізацію та розвиток культурного потенціалу, якій був би націлений в сторону європейського освітнього простору. Саме цього вимагає доктрина освіти в Україні. Важливого значення набуває підвищення рівня професійної підготовки майбутніх учителів музики, що обумовлено основним завданням учителя - формуванням музично-пісенної 